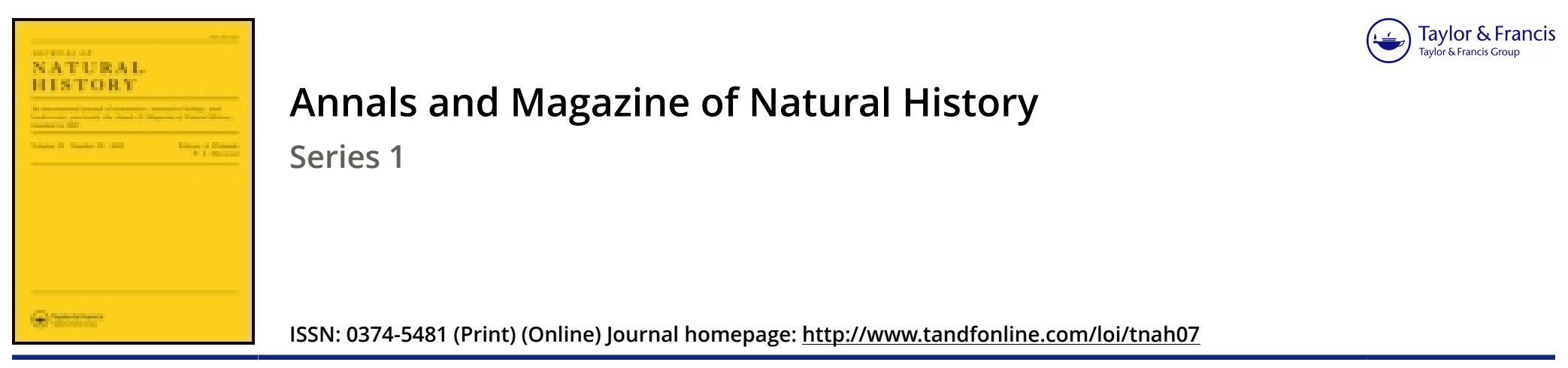

\title{
LI.-On the British species of Grammonema and Eunotia
}

\author{
John Ralfs Esq.M.R.C.S., Penzance.
}

To cite this article: John Ralfs Esq.M.R.C.S., Penzance. (1844) LI._On the British species of Grammonema and Eunotia, Annals and Magazine of Natural History, 13:86, 457-461, DOI: 10.1080/03745484409442630

To link to this article: http://dx.doi.org/10.1080/03745484409442630

$$
\text { Published online: } 04 \text { Dec } 2009 .
$$

Submit your article to this journal $\lceil\pi$

Q View related articles $₫$ 
Some years since Mr. Waterhouse first discorered this insect near Dorking. I found it at Micklcham rather plentifully the berinning of October 1837, on herbage under the hedges, in the park behind the church; at Gravesend in June, Mrr. S. Stevens : it appears to be confined to chalky districts.

34. A. atomarium, Kirb., Gyll., Germ., Stcph. Man., Schönh. - pusillum, Germ.

This is the most minute species of the genus found in England ; it was originally described by MIr. Kirby from a Swedish specimen sent lim by Major Gyllenhal, and for many years it was unknown as a British insect until Mr. Waterhouse found it near Dorking. In a note from Germar relative to this species, he informs me that the "Ap. atomarium of Kirby is, without doubt, identical with the Ap. pusillum of Germar."

Taken in abundance at Birch Wood on the wild thyme (Thy)mus Serpyllum) in September by Mr. S. Sterens, MIr. Smith and myself, and occasionally in other places on the same plant.

35. A. vicinum, Kirb., Germ., Steph., Schönh.

- Loti, Gyll.

- incrassatum, Germ.

Very rare in the south of England, but I found it in Yorkshire in profusion on the black thorn (Prumus spinosa), growing on a hedge-bank by the side of a ditch full of rushes in a marshy situation.

36. A. Hookeri, Kirb., Germ., Gyll., Steph., Schönh.

I have frequently taken this insect in abundance in Yorkshire by sweening in clover-fields (Trifolium pratense), particularly in a ficld near Low IIarrowgate, in June and Septenber; and plentifully near Southampton in June; one cxample was found at Gravesend in June, and another at Shirley Common in Septenber, by MIr. S. Sterens.

[To be continued.]

LI.-On the British species of Grammonema and Eunotia. By Joun Ralrs, Esq., M.R.C.S., Pcnzance*.

[With a Plate.]

Grammonexa, $A g$.

Filaments gelatinous, clongated, flecible, not fragile; frustules rectangular, plane, not striated, scarcely siliceous.

In appearance this genus comes very near to Fragilaria, with which it is united by most writers, but its labit is so very differ-

- Read before the Botanical Society of Edinburgh, Felruary $8 \mathrm{th}, 181$. Ann. \& Mag. N. Hist. Vol. xiii. 
ent that I am inclined with $\Lambda$ gardh to licep them distinct. In Fragilaria the flaments are rery fragile, loreaking in pieces at the slightest touch; the species do not adhere well to paper; the frustules are siliccous and glass-lilic, and may be subjected to a red heat without any other alteration than the destruction of the colouring matter, and at each end are two more or less cvident pellucid puucta.

In Grammoneme there is scarcely any silica, in which important character it differs from most of the Diatomacea; the filaments are not fragile and are hirglly mucous, adhering firmly to paper or glass, and when dried appearing like a mere stain ; the application of nitric acid or a red leat destroys their form, and I can perceive no puncta at the ends of the fiustules.

The filaments are elougated, ribbon-like, and composed of numerous frustules which are longer than broad.

1. G. Jurgensii, Ag. Filaments attenuated, yellowish-brown; frustules three to eight times longer than broad, slightly separated at the angles. Ag. Consp. Diaton. p. 63. Fragiluria Jurgensii, Ktz. Synop. Diatom. in Linnea 1833, p. 587. Fragilaria aurca, Carm. in Hook. Br. Fl. vol.ii. p. 403 ! Harv. Br. Alg. p. 198. Conferva strialula, Jurgens, Dec. 19, no. 6 ! (not Conf. striatula, Dec. 11, no. 7.).

B. diatomoides. Filaments turning green when dried. Fragilaria diatomoides, Grev. in Hook. Br. Fl. p. 403 ; Harv. I3r. Alg. p. 198; TVyatt, Alg. Damn. no. 233!

On marine alga : spring.

a. Appin, Capt. Carmichael; Antrim, Mr. D. Moore; Land's End and Penzance.

B. Kilkee, Mr. Harvey; Torquay, Mrs. Griffiths; Mount's Bay.

In a mass both are dark brown, but much paler if separated in the water. In $a$ the colour is but little altered in drying, but in $\beta$ it becomes green.

Filamcuts clongated, giving a feathery appearance to the plant to which they are attached, very mucous, flesible, gradually attenuated; frustules under the microscope nearly colourless, threc to cight times longer than broad, plane, slightly attenuated at both cnds, and henee disconnected at their angles, and as the cnds are also often somenhat rounded, the margins of the filament have a crenate appearance.

Mrr. Harrey, to whose liberality I an indebted for specinens of many of Capt. Carmichacl's plants, has fircn me a portion of a specimen of ' Fragilaria aurea' gathered by Carmichael himself, and also Irish specimens both of that plant and of 'Fragilaria diatomoides' of Greville. 'These I have attentively exanined; as irell as specimens gathered at lorquay and Penzance, and I 
regret that I camnot detcet any character to distinguish ' Frag. aurea' from ' Frag. diatomoides,' cxcept that the latter in drying changes to a green colour.

The following extracts from their letters will show that my opinion has been confirmed by the observations of MLrs. Griffiths and Mr. Harrey, who at my request compared these plants.

Mrs. Griffitls writes, "I have examined your specimens of ' Fragilaria aureet' very carefully, and compared them with ' Fragilarị e liatomoides' from Torquay, gathcred at different times, and can find nothing to distinguish one from the other."

Mr. Harvey observes, "I fear youl are right about 'Fray. aurea" if colour be not in itself a specific character."

Mr. Berkeley has euabled me to compare our plant with the ' Conferra striatula' of Jurrens' $\Lambda$ lgax, and thus to assure myself that it is completely identical with Ju'gens', which is doubtless the 'Grammonema Jurgonsii' of Agardlh.

Plate XIV. fig.5 . Grammonema Jurgensii $: b$, single frustule ; $c$, lateral view.

\section{Eunotis, Elhr.}

Frustules frec, simple or binate, quadrangular, with two puncta at each end; the front is flat or concare, and the dorsum convex; the lateral surfaces are flat.

Some species placed by Fhrenberg in this genus have cymbi-

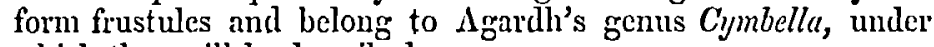
which they will be described.

In Eunotia the frustulcs resemble those of some species of Fragilaria, from which the present genus differs only in not having its frustules united into a filament.

Viewed laterally the frustulcs are lunate. The lateral surfaces are flat, and do not enter into the front view, which is quadrangular with two puncta at cach cnd. Longitudinally the front is flat or concave and the dorsum convex; the convex surface is generally raised in transyerse ridges, and the number of these ridges, as seen in a lateral view, when they appear like tecth, distinguishes the specics.

Professor Bailcy suspects that "the number of these tecth is liable to variation, and that the number of species has in consequence been made too great*."

1. Eu. monodon (Ehr.?). Lateral view concave on one margin, convex on the other and constricted near the ends; strix none or very obscure. Bailey, Amer. Bacil. in American Journal of Science and Arts, vol. slii. no. 1. pl. 2. f. 28.

In freshwater pools. Piltdown Common near Uclifield, Sussex, Mr. Jenner; Penzance.

- See American Journal of Science and Ärts, vol. xlii. No. 1. 
The frustules are very minute, but vary greatly in length, being in some specimens only twice as long as broad, and in others six or seven times longer than broad.

The front view has its ends slightly rounded and its puncta very obscure. In the lateral view the shorter frustules are more turgid on the back, and more constricted near the ends. Although the frustulc scems in general to have no strire, I believe that this apparent deficiency is owing to the minute size of the specimens which have come under ny notice, as I have occesionally obscrved very faint latcral strix.

$\Lambda$ frustule of this species, though very much smaller, has great resemblance to a solitary frustule of Fragilaria pectinalis; but in this plant the concavity of onc margin is generally grcatcr, and the constriction near the ends of the frustule more considerable; the front view, too, is narrower in proportion to the lateral ; still it may eventually prove to be only the commencement of that plant.

In the 'American Bacillaria' there is no description of this species, but as Bailey's figure represents a larger plant, with distinct lateral stria, it is probably taken from a more naturc specimen.

Plate XIV. fig. 1. Eunotia monodon: $a$, front view; $l$, front view of frustules deprived of their colouring matter; $c$, lateral viers.

2. Eu. diodon, Ehr. Lateral view striated, with the convex margin bidentate. Ehr. Infus. p. 192. t. 21. f. 23 ; Pritch. Infus. p. 214; Bailey, l. c. pl. 2. f. 29.

In freshwater pools, very rare. Penzance, $J . R$. ; Piltdown Common near Uckfield, Sussex, Mr. Jenner.

Front view about trice as long as broad, with tro distinct puncta at each end, and the terminations of the lateral strix evident along the lateral margins. Lateral vicw much narrower ; the margin on oue side that or slightly concave, on the other convex with two rounded elevations and a constriction near each end; the lateral strix are very distinct. The transverse ridges on the dorsum appear much more considerable in the shorter than in the longer frustules.

The figure in the 'American Bacillaria' represents a larger plant than the specimens $I$ have secn, but agrees with then in other respects.

This species differs from Eunotia tetraodon in the number of ridges on the dorsum, which is less rounded, and in having the lateral surface much narrower than the front, and one of its margins flat or slightly concare.

Peate XIV. fig. 2. Eunotia diodon: $a$, front view; $b$, lateral view. 
3. Eu. triodon? Ehr. Frustules with three ridges on the dorsum. Ehr. Infus. p. 192. t. 21. f. 24; Pritch. Infus. p. 214. f. 164?; Bailey, l.c. pl. 2. f. 30.

In Cold Bath Spring near Tunbridge Wells, Mr. Jenner.

Frustules very minute, with two indistinct puncta at cach $\mathrm{cnd}$. The lateral view is slightly concare on one side, and on the other convex with threc dentations; strix wanting or indistinct.

The form of this species greatly resembles a single frustule of Fragilaria pectinalis $\beta *$, but is smaller; the protuberances also are larger in proportion to the size of the plant.

The figure in the 'American Bacillaria' is much lar'ger' and has distinct lateral strixe, and was probably taken from an older specimen.

Prats XIV. fig. 3. Eunolia triodon: $a$, front vicw; $b$, lateral viers.

4. Eu. tetraodon, Ehr. Frustules with four ridges on the dorsum; lateral strix distinct. Ehr. Infus. p. 192, t. 21.f. 25; Pritch. Infus. p. 214 ; Bailey, l. c. pl. 2. f. 31 .

In boggy pools, rare. Dolgelley and Penzance, J. R.; Weston Bogs near Southampton, Mr. Jenner.

This is a large species : in the front view the puncta arc listinct; in the lateral view one margin is very concave, and the other very convex with four large, rounded elcrations, and a constriction near cach cud. The strongly marked strix slightly converge towards the concave margin.

P'Late XIV. fig. 4. Eunotia tetraodon: $a$, front vicw; $b$, dorsum; $c$, lateral view.

LII.-Description of a new Genus of Golioid Fish. By Jonn Richardson, M.D., F.R.S. \&c.

To Richard Taylor, Esq.

MY dear Sir, Haslar Hospital, 17 th $A$ pril, 1814.

I SEND you the generic characters of a gobioid fish discovered by Sir James Clark Ross at Kergueleu's Land, on his recent antarctic voyage. 'The genus will occupy a place in the system near Callionymus and Trichonotus, and affords a connecting link between the Gurnards and Gobies.

$$
\begin{aligned}
& \text { I remain, dear Sir, yours faithfully, } \\
& \text { Joun RicuILRDSON. }
\end{aligned}
$$

\section{Channichtirys, Richardson.}

Caput magnum, cranio scabro, subtetragono; facie horizontali, depressiuscula, ante oculos longa, lateraliterque per parietes oris membranaceos aucta.

Faux laxissima, horizontalis, terminalis; rictu superne ab ossibus

* This may be the Fragilaria trionodis, Ehr., a specics I am unaequainted xith except by name. 